\title{
Nursing in an Emergency Unit: Interfaces and Interdependences of the Work Body ${ }^{1}$
}

\author{
Rejane Moschen ${ }^{2}$ \\ Maria da Graça Corso da Motta ${ }^{3}$
}

\begin{abstract}
The aim of this study was to understand how the nursing team perceives its interdependence within the work body of the emergency unit. The study used a qualitative descriptive approach with the participation of three registered nurses, six nursing technicians and two nursing assistants from the largest public emergency unit in Porto Alegre, Brazil. The Creative and Sensitive Method was used for data collection, with reflection workshops and content analysis, providing three categories: Perceptions of the body; relationship of the body systems; and the nursing body in the emergency unit. The results revealed the interdependence of the members in the work and a certain impotence and frustration emerged due to the overload of the nursing body and to the (un)caring within the context of intense human productivity of the emergency services. Moments of reflection about the biological body allowed the team to visualize and feel themselves essential in the group, revealing an efficient care strategy to the nursing caregiver.

Descriptors: Nursing; Emergency Nursing; Nursing, Team.
\end{abstract}

\footnotetext{
${ }_{1}^{1}$ Paper extracted from course conclusion monograph "Interfaces das relações de trabalho na equipe de enfermagem: o desvendar de um corpo em sua interdependência" presented to Escola de Enfermagem, Universidade Federal do Rio Grande do Sul, RS, Brazil.

${ }^{2}$ RN, Specialist in Cross Infection Control and Hospital Management, Grupo Hospitalar Conceição de Porto Alegre, RS, Brazil. E-mail: rejanem@ghc.com.br.

${ }^{3}$ RN, Ph.D. in Nursing, Professor, Escola de Enfermagem, Universidade Federal do Rio Grande do Sul, RS, Brazil. E-mail: mottinha@enf.ufrgs.br.
}

Corresponding Author:

Maria da Graça Corso da Motta

Universidade Federal do Rio Grande do Sul. Escola de Enfermagem.

Departamento de Enfermagem Materno Infantil.

Rua São Manoel, 963

Bairro Santa Cecília

CEP: 90620-120 Porto Alegre, RS, Brasil

E-mail: mottinha@enf.ufrgs.br 


\section{Enfermagem em unidade de emergência: interfaces e interdependências do corpo de trabalho}

O objetivo deste estudo foi conhecer de que modo a equipe de enfermagem percebe sua interdependência no corpo de trabalho em emergência. A abordagem usada foi qualitativo-descritiva, participaram três enfermeiras, seis técnicos e dois auxiliares de enfermagem da maior emergência pública em Porto Alegre, RS, Brasil. Na coleta de dados, utilizou-se o Método Criativo e Sensível, com oficinas de reflexão e análise de conteúdo, suscitando três categorias: percepções de corpo, relação dos sistemas no corpo e corpo de enfermagem em emergência. Os resultados revelaram a interdependência dos membros no trabalho e emergiu certa impotência e frustração pela sobrecarga do corpo de enfermagem e pelo (des)cuidado no contexto de intensa produtividade humana dos serviços de emergência. Os momentos de reflexão sobre o corpo biológico permitiram à equipe visualizar-se e se sentir fundamental no grupo, revelando-se estratégia eficiente de cuidado ao cuidador na enfermagem.

Descritores: Enfermagem; Enfermagem em Emergência; Equipe de Enfermagem.

\section{Enfermería en una unidad de Urgencia: interfaces e interdependencias de la fuerza de trabajo}

El estudio tuvo por objetivo conocer de qué modo el equipo de enfermería percibe su interdependencia en el cuerpo de trabajo en la unidad de urgencia. Con abordaje cualitativo-descriptivo participaron tres enfermeras, seis técnicos y dos auxiliares de enfermería de la mayor unidad de urgencia pública en la ciudad de Porto Alegre, en Brasil. En la recolección de datos se utilizó el Método Creativo y Sensible, con talleres de reflexión y análisis de contenido, que produjeron tres categorías: percepciones de cuerpo, relación de los sistemas en el cuerpo, y el cuerpo de enfermería en urgencia. Los resultados revelaron la interdependencia de los miembros en el trabajo y emergió cierta impotencia y frustración por la sobrecarga del cuerpo de enfermería y por el (des) cuidado en el contexto de intensa productividad humana de los servicios de urgencia. Los momentos de reflexión sobre el cuerpo biológico permitieron al equipo visualizarse y sentirse fundamental en el grupo, revelándose una estrategia eficiente de cuidado al cuidador en la enfermería.

Descriptores: Enfermería; Enfermería de Urgencia; Grupo de Enfermería.

\section{Introduction}

This study is derived from the experiences in the hospital area of a public emergency service, emerging in the discourse concerning the interdependence of members in the nursing team. I was intrigued by the repeated, medically certified, absences among the nursing staff, especially in the shifts with more interpersonal conflicts. Those absences caused a redistribution of patients by nursing professionals on the nursing roster and therefore, a care overload. I proposed, as a nurse, to investigate possible ways to sensitize and unite this group in a body of work. While attending a lecture on "Physiology of the human body", how interconnected systems influenced the functionality of the body, the idea occurred to me of representing this, through ludic means, in the investigation of this interdependence of the nursing team.

Nursing is a human science of direct interaction among people with knowledge production about the cared being, grounded in the practices of health and disease. Due to this it requires the professional capacity 
for reflection, for critical analysis and for the constant search for improvement of their technoscientific knowledge $^{(1)}$. The social division of labor, the religious spirit and the military organization influenced the foundations of the professionalization of care, sometimes fragmented by the division of tasks in the teams, sometimes marked by disregard of the other - ally and partner - in the relationships of interdependence and complementarity(2-3) much needed in health services. Team members sometimes do not realize or do not openly discuss their difficulties and needs in interpersonal relationships, regardless of how their actions can affect the body of work. Absenteeism can be directly related to working conditions, where the lack of spaces for reflection on this production and interaction in the care produces dissatisfaction in the quality, productivity and personal life of the nursing staff(1).

Studies indicate the need to use strategies of care with the nursing caregiver in health services ${ }^{(1-3)}$. The production of collective reflection through the human body and the body of work permits the nurse to comprehend and interpret the meaning of their life, becoming aware of their representation in the world(4), considering that the body experience, in the exterior and interior environment of the body itself, may manifest different perceptions in coping with the phenomena of pain and suffering ${ }^{(5)}$.

By drawing a parallel between the dynamics of nursing work it becomes evident that the group overload and the emergence of dysfunction (lack of motivation and illness) from one of its members can be compared to the organism's physiological function when one of the body systems starts to operate with a disability in its vital functions. Considering that these interconnected structures are designed to maintain the automation and continuity of life ${ }^{(6)}$, it is known that they can be affected by stressor processes causing bodily imbalance with deleterious responses to other organs ${ }^{(7-8)}$.

Physiology enriches the understanding of the interdependence of cellular organs, when grouped by distinct functions called physiological systems. The skeleton protects the internal organs - is a lever for the movements - forms blood cells. The muscular system permits movement; the circulatory and lymphatic system distributes blood and lymph and nourish the body; the respiratory system is responsible for gaseous exchange (oxygen and carbon dioxide) between blood and air ${ }^{(9)}$ and, successively, each system has a vital function in the body. Thus, the dynamics of the biological body were used as an analogy for the functional dynamics of the nursing team in their relationships and inter-relationships in the work environment. Therefore, the aim of this study was to understand the perception of the nursing team in an emergency unit and their interdependence as a work body, by anatomic references of the human body and of the sensitive body.

\section{Methodology}

This is a qualitative, exploratory and descriptive study, carried out in the largest emergency unit of the public health system in the south of the country, in Porto Alegre, linked to the Ministry of Health, which attends adult patients in clinical, surgical, gynecological and dental specialties through the Unified Health System

The participants, selected from among the members of the nursing team working in the unit, were: three registered nurses, six nursing technicians and two nursing assistants with length of employment between three months and 19 years.

The project, respecting the standards of research with human beings ${ }^{(10)}$, obtained approval $n^{\circ}$. 076/04, from the Research Ethics Committee of the Hospital of the study, the signature of the Free Prior Informed Consent form and guaranteed the anonymity of the subjects by means of anatomic-physiology pseudonyms: Lymph, Oocyte, Neuron, Nephron, Erythrocyte, Alveolus, Epithelium, Patella, Fiber, Mouth and Pupil.

Data collection occurred from September to October 2004, through the Creative and Sensitive Method, which relies on the principle of Freire for the construction of knowledge from the group discussion. In it, participants are free to express their ideas and opinions "showing the facet hidden in the original theme"(11). This is an educational method and a powerful tool for creating group awareness in the collective production of knowledge about the causes of problems and making solutions possible.

The structure of the Creative and Sensitive Method develops in the "triad: group discussion; participant observation; and dynamics of creativity, sensitivity and artistic production"(11), involving workshops, using various techniques - drawings, collages, clippings, modeling, among others - for the production and purpose of data collection for the research. In this methodology, the planning of dynamics, the script of activities and recording the discussions stand out.

This modality was developed in four stages: first - the group welcoming, purpose of study, guidance on the dynamics; second - the presentation of the research question, providing the ludic material and artistic 
production (individual or group); - third, presentation of productions and collective discussion; and fourth moment of synthesis and validation of the reflections.

The workshop, with the dynamic denominated "Knowledge of the Body", occurred in three meetings with the following thematics: Perceptions of the body, Inter-relationship of physiological systems, and Body of emergency nursing. The guiding questions were: in the first workshop - what is the meaning of body for each participant?; in the second - what are the interactions of physiological systems in the body's functioning and their relationship to teamwork? Here, each member represented a physiological system, for example: I am the system ... and I perform these functions in the organic body. And in the third (final) workshop - what is the perception of the work in emergency as the nursing body.

For interpretation of the information the content analysis of Minayo ${ }^{(12)}$ was used, comprising pre-analysis from the information obtained in the three workshops of creativity and sensitivity, the statements were transcribed and grouped by categories. Next came the exhaustive exploration of the material, with three categories arising in response to the thematics of each workshop and the interpretation of results.

\section{Uncovering Meanings}

The following results address the construction of the group, through ludic means, of interpretations of the human body and body of work through the guiding questions in each workshop. The subjects, as unique people, through their creative work freely presented the perceptions of body in the nursing work which emerged in the following categories.

\section{Perceptions of the Body}

The profession of nursing care is an art because it requires all the dedication, like that of an artist to produce their work of art(13). The professional practice requires the basic premise of sensitivity and respect for unprotected bodies and for those that are given to these beings also consisting of bodies, as objects of care, revealed in the phrase: $I$ read [...] that the body is like a canvas: the painter paints the canvas and it is a dead canvas, a canvas that has no life! And, for us of nursing, no! We work as if we were a canvas that has life and feelings! I think the body is that (Pupil). The body (in the drawing) on the floor seems to me that it is [...] I remember the music of Chico Buarque: there's a body lying on the ground. [...] without life, without soul, with nothing! (Nephron).
The body, in the dimension represented by the participants, reports to the condition of human existence, with peculiarities of each individual in the coexistence of to feel and to be felt, to touch and be touched. Man, in his corporeality, is reason, spirit, affection, is an ethical, moral being and gregarious in relationships, embodied in a living body(4). Becoming conscious of corporeality broadens the horizons as to the finitude and temporality of existence. It allows the person to rethink their behavior and desire a threshold of humanity in their actions, becoming ethical, moral, and capable of providing life, to love and to be loved.

\section{Relationships of the Body Systems}

The dialectic thought of the $I$ "I have no body, I am the body"(4), makes it clear that through it I perceive and I am perceived not only as an object, as I manifest forms of relationships, work, feelings and conflicts.

The $I$ is represented in the inter-related physiological system of the subjects, making them feel part of the whole. The representation of the human may involve multiple views, but when directed to ludic expression, based on scientific concepts and definitions, allows the subjects to give themselves to the creative dimension and find meaning in the act of playing. Erythrocyte saw the circulatory system as moving through the body, promoting metabolism: I am the circulatory system! Without a doubt I am the most important system of the human organism, because I walk around all of it, irrigating, transmitting energy, oxygenating the tissues and promoting metabolism! (Erythrocyte)

Alveolus felt himself as being an essential mechanism for survival: I am the respiratory system, important for human survival! Without air no human survives! (Alveolus).

The experience of entering into an organic system would have no value except as a realization tool regarding the role of each member in the exercise of their function in the nursing team. It is, in the execution of daily tasks, that nursing most expresses the I need the others to develop which alone would require more effort, or perhaps not be brought to term. The following dialogue reflects this functional interdependence: Work teams should be like a body! [...] Every organ, depends on another, but sometimes is not so! (Neuron). It is, neither one is more important than the other! (Oocyte). All are important, but if one does not work together, then the other works even more, so ... (Neuron). So, overloads the other, then ... (Oocyte) becomes sick. It's like a body ... (Neuron). For a while it can keep working, but there will come a moment that if it is damaged, the whole thing will become out of balance! (Oocyte). 
The professions involved with care, due to emotional and physical demands regarding their work, require an integrated team able to assume the responsibilities of the work. The events considered threats to the state of equilibrium can result in imbalance, due to the functional inability to cope with difficulties, and can generate physiological, emotional, cognitive or behavioral changes illness or individualism in the work team ${ }^{(6,8)}$. The adaptation and maturation in the face of conflicts are inherent to human corporeality, whether in work, in the family or in the individual sphere. The development of ludic spaces conducive to group reflection on action in nursing care seems to emerge as an essential therapeutic measure.

The legacy of the Industrial Revolution in the division of tasks and the biomedical concept sustains the current care model, focused on "attention to the disease and the completion of the task, not the individual"(14). The areas of expertise among professionals are guided by the definition of functions. Nursing is governed by a hierarchy with enabled functions distinct among the technoscientific knowledge. The following statement then reflected on the organizational interdependent enterprise: It is like the body, if one part fails the other will not continue! It is no good for the doctor to prescribe and I go there and do not do or do just half! He asks to observe bleeding or control diuresis and I do not write it down. [...] the information I have to pass, I'm not passing! Then it will not work! (Patella). Because of this [...] you have to have a head, a coordinator, otherwise it becomes a mess! If everyone has the same degree of power, there may be disorganization. [...] someone who knows how to give the opportunity for members of this body to put their ideas; and to have the humility to accept, manage and listen to all, respecting them. (Erythrocyte)

The need expressed by Erythrocyte, refers to the relevance of the role of the nurse in the function of coordinator of the team. The nurse, a care agent, is also responsible for organizing the collective work - producing the nursing roster, supervising the staff, ordering material goods and repairs - seeking operational success of the care. However, the demands of the working group are also a management responsibility of this professional.

Ludic moments foster stimulus to that body because it is a way of living, of being and of doing, of playing(11). The aspirations expressed by the subjects entwined themselves in the literature diving and finding ways to valorize creativity and to express feelings that otherwise would not be revealed to the team.

\section{The Nursing Body in the Emergency Unit}

The peculiarity of the profession of care requires a person to be with presence, open to welcome the various manifestations of the individual. The relationship of unity and support among the members stands out in the statements of the protagonists, which touch on the relationship of complicity in the team: I think it's a great environment to work! People who work in emergency end up united. (Epithelium) My little soldier has a sense of unity: when one is bad the other carries! In that sense, I think it's good in the emergency department! (Lymph) I made a stretcher with a person lying down and two of the nursing team carrying it, which symbolizes the teamwork. A single person is unable to transport the patient! The team is important for nursing! One helps the other (Pupil).

The interaction scenario draws attention to the experiential interdependence of this body of work. The perception of unity and cooperation between the elements of the nursing team engenders a certain job satisfaction in the emergency environment. However, the quotidian care of know-do finds itself directed to meet institutional demands, to the detriment of the interpretive interaction of care of oneself in the attention to the other. An intrinsic desire to comprehend and be comprehended in their differences with the other was expressed: There are people with different temperaments working together and sometimes we want them to understand our way, but, due to the lack of time, you cannot understand the colleagues. [...] we feel bad ...! We are also human and the people are sick! But we also suffer and sometimes end up getting sick because of it! (Oocyte).

The reflection points to the complexity and fragility of everyday human interaction in the work team. There is a need to make opportunities for collective moments to reflect and be with the other so as to integrate and harmonize the differences in the group. A body (the team) should be explored as the puerpera does at the first inspection of the newborn to identify it, to make it hers. The neglect relative to the dimension of feeling part of and integration between the elements of the nursing team can be the cause of illness and absence from work. However, summations of events are needed to balance the body, but it is assumed that healthy spaces with people accepted and liked by the group can contribute to maintaining a healthy body.

In the following dialogue, the nursing team is shown to be sensitive and fragile in the construction of knowledge and actions of life and of love for the other. Mouth, a nurse, designed the shape of the sun, symbolizing the universe of multiple attention and interaction, typical of the performance in places of intense demand, such as the emergency departments in public institutions: Everybody calling! Everyone wanting 
attention! And you there, trying to radiate to everybody, but sometimes you can't! (Mouth) We say so often: Just a bit! And when the other side (patient) asks for something and people tell you: Just a little! My God! It's terrible! Then I think: Wow! As I say: Just a bit! (Erythrocyte).

From this reflection, emerges a being tuned to the desire for care of the other, however, the forms of work do not translate into the immediacy of action, because they collectivize themselves in a crowded space of subjects with different needs. The constant overcrowding of emergency units due to the lack of beds for hospitalization in the Unified Health System (SUS) generates an impact on standards of care and ethics of the professionals who work there ${ }^{(14)}$.

In the nursing participants' perceptions a body becomes evident marked by demands for care and chores that generate feelings, sometimes of frustration and demands, sometimes of pleasure and joy. The feeling of frustration is related to the overload of activities. The intrinsic desires of the subjects are revealed in how they would like to produce quality work: I cannot manage to perform all the work the way I would like to: within your working day [...] you have to make the prescription and nursing care and $[. .$.$] it becomes humanly impossible to give a quality service$ (Erythrocyte). [...] Because it is so rushed that, when I get home, I start thinking: a patient of mine called me and asked me for something, at the time, it was not a priority - because there you always have to see the priority - only that for him, that was priority! [...] This also makes me tired! It is not only the physical work; it is not being able to do everything and to feel pressured (Oocyte).

The discourse reveals emotional distress that may trigger a stressor state in the body. The caregiver is aware of their role in the preservation of care and, sometimes, this extends from the original preoccupations of work to beyond the hospital space. A study on selfmedication among the nursing staff indicates that those professionals "excessively committed to the work, who cannot manage to stop thinking about work even during their time off", make greater use of self-medication ${ }^{(15)}$.

The biomedical conception and scarcity of human and technological resources favors the centrality of care focused on patients in emergency situations, to the detriment of those stabilized, when in the emergency service, waiting for a bed. A sense of frustration at failing and in not getting the expected is apprehended, which can cause severe impact on the state of equilibrium of this body, when triggering adaptive mechanisms specific to each individual: We are pressured: by the patients, by the relatives. When the visitor enters, that becomes a horrible stress! They want minimal things, [...] and we're rushing with the medication! Sometimes I feel like saying: I'm full of things to do, I cannot get these things now! But, for them, these things are important, it makes you think: ... and if it were someone of my family and I went and saw that they were thirsty? [...] And it wears you out not managing to get things done. You have to be always rushing. [...] we are also pressured by the managers! Of course, they pressure because they are also pressured [...] and this I find very stressful (Oocyte)

It was understood from the discourse that the problem was not from the pressure, but from the stress of the volume of tasks. Sometimes the family also contributes by increasing the physical and mental overload; and sometimes the supervisors find it their duty to pressure because they are also pressured. "The hostility that the individual encounters in this environment can be understood as the intensification of manifestations related to the evolution of the classic hospital culture of isolation, to the impersonal attitude supported by the technicality or positivist medical scientificism, and to the defense mechanisms due to the outrageous work conditions"(14).

The reflection of the workers in a team body assumes respect for the space and the action of each member in order to favor a harmonious, pleasant working environment, which does not generate suffering or illness, and a sensitive leadership open to change. The praise or gratitude emerges as feed(back) for the body ritualized with nursing chores: I think it is very cool, when a family praises us! We miss being praised by someone! Sometimes [...] when sitting for a while, someone comes and says: Hey, you sitting there! It seems like you have nothing to do. (They all laugh.) I think that the praise and recognition, once in a while, is very good! It lifts us a lot! (Oocyte) It raises the self esteem! There are hospitals that stick things on the board, praise for the employee of the month because they performed their work well. [...] Reward, encourages the employees to organize themselves! (Neuron)

The recognition and valorization expressed by Neuron communicates the expectations of the subjects faced with their work. This space of reflections aroused in the nurse their role in managing the team: I never realized the importance of praise and, sometimes, [...] I know that I should give a compliment and I end up not giving it because I am in a rush. Actually, today I saw your roster [of patients] and you had everything organized! (Epithelium)

The creation of space for dialogue between the constructors of the work relationships defined in a materialized body, allowed the importance of praise to be realized and started to exercise, in the agents, a 
transformation by opening and listening, essential to the dialogue: It is not that we do the things to receive praise, but, when we get dressed up, we like it when the boyfriend takes notice; we stay like this: waiting for a compliment! It's good! Everyone likes it! (Oocyte). By saying that we dress up and like that the boyfriend takes notice, Oocyte expresses the true way of nourishing the nursing body and making it competitive; not to individualize it, but to stimulate it in its singularity.

\section{Reflections of the Corporeity in Nursing}

In the various stages of the investigative process, the singularity of each moment was observed, happy individuals, with definitions sometimes similar, other times peculiar, baring a body constituted by themselves. The interdependence emerged strongly turning into uneven wisdom: whereby it is impossible to think of a team ignoring its members. The reflections permeated the imbalance between body and work, the inequalities in the interdependence and the strengthening of the team inter-motivation.

The corporeity seems to overlap the difficulties because it finds resonance in the pleasurable perceptions of its members. Despite the great demand for services, there is a collective consciousness of to be serving and perhaps therein lies the happiness and pleasure experienced. The intimate satisfaction of the being (their Ego) passes through approved social attitudes and between the spaces of the hospital work; the emergency unit is the place of greatest power of immediate help in the alleviation of the pain of the individual, however, it increases the risk of emotional hardening in the caregiver, due to daily exposure to such extremes. The representations permitted the apprehension of a context of agility in the collective care, help and cooperation with sometimes unity, sometimes disunity among the members, typical of a dynamic family. Friendship was highlighted as a maintaining element of this body that is complemented in the union of the pieces in the day-to-day.
In the reports, the nursing leadership was cited as essential in the organization of the activities of the team. However, their mediating role in the impasses, concerning the culture of each individual, revealed a scenario of intense discussions. Nevertheless, individuals capable of discussing manifest their essence, motivating themselves in a process of maturing in the relationships, adapting it to conflicts as part of the human corporeity in its existence, whether in work, in the family or in the personal being. Humanization enables them to comprehend that each element has its own singular and unique space in the team, and differentiates them from the machine.

The members, especially the nursing assistants or nursing technicians, strengthened their self-esteem when knowing that they were essential in the operation of the organizational body. However, they apprehended, in their interdependence, the desire of shared responsibility in the production of the work. The manifestations reveal that the failure or neglect on behalf of one of the members leads to overload, to illness and to imbalance in the body. The enlargement of the consciousness in the rescue of the team body aroused the ideal of equality in the subjects.

Nursing needs to rescue the essence of its profession, to demystify the ideal of power that dims its luster and liberty. The construction of healthy relationships between the different teams in the hospital scenario requires the ability to accept differences and open communication in the interaction of the quotidian, in which people start to know themselves, denote values and conquer wisdom by being with the other, tracing healthy links of professionalism in the work team.

Finally, the study revealed beings profoundly human, seeking to satisfy the needs of the other, even if limited by the context of the intense human production, a characteristic of emergency units. The moments of reflection on the biological body allowed the team to visualize and feel themselves as fundamental in the group and proved to be an efficient strategy to care for the caregiver in nursing.

\section{References}

1. Becker SG, Oliveira MLC. Estudo do absenteísmo dos profissionais de enfermagem de um centro psiquiátrico em Manaus, Brasil. Rev. Latino-Am. Enfermagem. 2008; 16(1): 109-14.

2. Vieira ABD, Alves ED, Kamada I. Cuidando do cuidador: percepções e concepções de auxiliares de enfermagem acerca do cuidado de si. Texto \& Contexto Enferm. 2007 jan-mar; 16(1):15-25.
3. Lima RCD. A enfermeira: uma protagonista que produz o cuidado no cotidiano do trabalho em saúde. Vitória (ES): Edufes; 2001. 260 p.

4. Polak YNS. A corporeidade como resgate do humano na enfermagem. Pelotas (RS): Universitária/UFPel; 1997. 151 p.

5. Santana MTBM, Jorge MSB. Corpo próprio como experiência vivencial da enfermeira não cuidar do outro no processo de morrer. Rev. Latino-Am. Enfermagem. 2007; 15(3): 466-73. 
6. Guyton ACA. Organização funcional do corpo humano e o controle do "Meio Interno". In: Guyton ACA. Tratado de fisiologia médica. 11 ed. Rio de Janeiro (RJ): Elsevier; 2006. p. 3-8.

7. Seyle H. The physiology and pathology of exposure to stress. Canadá: Acta Incorporation; 1950.

8. Smeltzer SC, Bare BG. Brunner \& Suddarth: tratado de enfermagem médico-cirúrgica. $11^{\text {a }}$ ed. Rio de Janeiro (RJ): Guanabara Koogan; 2009.

9. Di Dio LJA. Tratado de anatomia sistêmica aplicada. $2^{\mathrm{a}}$ ed. São Paulo (SP): Atheneu; 2002.

10. Conselho Nacional de Saúde (BR). Diretrizes e normas regulamentadoras de pesquisa envolvendo seres humanos: Resolução 196/96. Diário Oficial da União, de 16 outubro de 1996. Brasília: Imprensa Oficial; 1996. p. 21082-5.

11. Cabral IE. O método criativo e sensível: alternativa de pesquisa na enfermagem. In: Gauthier JHM, Cabral IE, Santos I, Tavares CMM, organizadores. Pesquisa em enfermagem: novas metodologias aplicadas. Rio de Janeiro (RJ): Guanabara Koogan; 1998. p. $177-203$.
12. Minayo MCS. O desafio do conhecimento: pesquisa qualitativa em saúde. 10 ed. Rio de Janeiro (RJ): Abrasco/ São Paulo(SP): Hucitec; 2007.

13. Watson J. Nursing: human science and human care, a theory of nursing. New York (USA): National League for Nursing; 1999.

14. Garlet ER, Lima MASD, Santos JLG, Marques GQ. Finalidade do trabalho em urgências e emergências: concepções de profissionais. Rev. Latino-Am. Enfermagem. 2009 jul-ago; 17(4):535-40.

15. Barros ARR, Griep RH, Rotenberg L. Automedicação entre os trabalhadores de enfermagem de hospitais públicos. Rev. Latino-Am. Enfermagem. 2009 nov-dez; 17(6):1015-22. 